\title{
Factors of commercial banks' loan eligibility of small businesses in South Africa: a construction industry case
}

\author{
Lindy Mtsweni \\ University of South Africa, Janadel street \\ Midrand 1686 South Africa \\ Philip Serumaga-Zake \\ University of South Africa \\ Jan Kruger \\ University of South Africa
}

\begin{abstract}
This study determines the factors that affect commercial banks' loan eligibility of small businesses in the construction industry in South Africa. A multiple case study design and six randomly selected small businesses (i.e., three unsuccessful-declined and three successfulapproved loan applicants) were used in this study. The qualitative methodology was applied to interview three senior managers from a commercial bank and six senior officials of the businesses, which had undergone the assessment process. The small enterprise assets finance applications of interviewed clients' outcomes and the credit scoring outcomes either formal complaint letters or minutes were also evaluated after the credit scoring decision had been made to obtain more in-depth data.
\end{abstract}

The main finding of the study was that client's relationship, background, character, collateral, capital, capacity and affordability are major factors of loan eligibility of small businesses in South Africa. Of particular importance was that, typical relationship-based term loans were based on a business relationship built over years of lending, allowing for substantial flexibility in loan terms.

Abstrak

Studi ini menentukan faktor-faktor yang mempengaruhi kelayakan pinjaman bank komersial dari usaha kecil di industri konstruksi di Afrika Selatan. Sebuah desain studi kasus ganda dan enam bisnis kecil yang dipilih secara acak (yaitu, tiga pemohon pinjaman yang berhasil dan tidak berhasil) digunakan dalam penelitian ini. Metodologi kualitatif diterapkan untuk mewawancarai tiga manajer senior dari bank komersial dan enam pejabat senior bisnis, yang telah menjalani proses penilaian. Aset perusahaan kecil mendanai aplikasi hasil klien yang diwawancarai dan hasil penilaian kredit baik surat pengaduan resmi maupun notulen juga dievaluasi setelah keputusan pemberian skor kredit dibuat untuk memperoleh data yang lebih mendalam.

Temuan utama dari penelitian ini adalah bahwa hubungan dan latar belakang klien, karakter, agunan, modal, kapasitas dan keterjangkauan merupakan faktor utama dari kelayakan pinjaman dari usaha kecil di Afrika Selatan. Yang paling penting adalah bahwa, pinjaman berjangka berbasis hubungan khusus didasarkan pada hubungan bisnis yang dibangun selama bertahuntahun pinjaman, memungkinkan untuk fleksibilitas besar dalam hal pinjaman. 


\section{INTRODUCTION}

According to the South African Government's National Development plan and policies report (2013), 90\% of new jobs should be created through Small Businesses by 2030, however progress has been disappointing (Mail Guardian, 2013). The World Bank (2013) adds that relative to larger firms, small businesses enhance competition, entrepreneurship, innovation, job creation and spur economy-wide efficiency; growth and poverty alleviation. According to the National Small Business Amendment Act (26 of 2003), a small business in the construction industry is a business with a total of 50 fulltime equivalent of paid employees, a total turnover of R6m and a total gross asset value (fixed property excluded of R1m. The SA commercial banks index (2013) revealed that the number of employers in the Small Enterprises sector has risen by $6 \%$ year on year and a growth in the number of businesses funded. However, Small Enterprises are faced with different challenges such as legislation, finance assistance and training, which lead to limited exposure and ability to expand their businesses (Financial Mail, 2013).

Regardless of business operational issues and challenges faced by the Small Enterprises like compliance, regulations and policies, lack of sufficient capital and credit facilities is often a major handicap to the development or growth of small businesses, especially in the early stages. Researchers allege that globally, 95 percent of small businesses rely on their personal resources, loans from friends and families or business partners to finance such business and result to failure in business (www.moneyweb.co.za).

This study focused on exploring the characteristics of small businesses whose finance applications are approved or declined after going through the assessment using the credit model of a commercial bank, the applied credit criteria by commercial banks in SA. The purpose of this study was to determine the factors that affect commercial banks' loan eligibility of small businesses in the construction industry in South Africa. In South Africa, the construction industry contributes 50\% market share to the commercial bank asset finance book followed by transport and the manufacturing sector

\section{LITERATURE REVIEW}

There is no clear evidence of what constitutes a successful-approved or unsuccessful-declined application for asset funding among small business. Most small businesses' credit requests are relatively small finance amounts and this is due to the costs of risk assessments and pricing dependent on the loan size, financed term, article type and if the article is going to be an income generating asset or not for the business (Commercial banks small businesses index, 2013). The study highlights the nature and common effects of challenges faced by growing or expanding small businesses in the construction industry.

Factors for firm growth: Financial inadequacies, which according to Beck (2007) are related to farm size, are key barriers to firm growth, leading to a mismatch between Small Enterprise demand and financial Institutions' supply of finance. Entrepreneurs across various sectors are experiencing challenges in accessing financial assistance to start or grow their business through financial institutions (Maas and Herrington, 2008) and this is due to rigid lending criteria and not meeting set requirements including collateral securities (FinScope Small Business Survey, 2010). Fal (2013) pointed out that the limited number of talented and skilled workers in South 
Africa means that small enterprise businesses often struggle to scale up; and that, although government had the best intentions to assist small businesses, all too often it introduced regulations that might be easy for big companies to adhere to, but which compounded the amount of red tape that smaller firms are faced with. Small Enterprise development currently faces serious constraints including the scarcity of long term financial resources like long term loans and venture capital (Wu et al, 2008) and as many entrepreneurs don't understand how to access the funds (www.mail\&guardian.co.za).

Asset funding: An estimated 5\% of small businesses in the construction industry have received asset finance for business expansion or growth from commercial banks, but the major challenge for commercial banks is the assessment of risk in a cost-effective manner. To this end, the commercial bank developed an internal automated credit scoring scorecard to determine if the small businesses should be financed or not.

Risk management: A bank regulation is a form of government regulation, which subject banks to certain requirements, restrictions and guidelines. This regulatory structure creates transparency between banking institutions and the individuals and corporations with whom they conduct business, among other things. Given the interconnectedness of the banking industry and the reliance that the national (and global) economy hold on banks, it is important for regulatory agencies to maintain control over the standardized practices of these institutions (www.globalbankreport.co.za). Commercial banks operate within a number of statutory requirements including the National Credit Act, Credit Agreement Act and Usury Act which impose additional constraints to the lending of small enterprise clients because certain requirements must be considered before the transaction is presented for consideration.

Temtime and Pansiri (2004) stated that high investment in fixed assets particularly during the start-up stage, inadequately estimated capital requirements, inability or failure to analyse financial statements, misperception of turnover as profit and under-utilisation of company assets are some of the factors leading to Small Enterprise failure at the infancy stage. The advantages associated with using debt finance are: Amount borrowed can vary according to needs; It does not dilute shareholding provided it is paid back; and There is no interference by the bank provided regular payments are made. The disadvantages are: It creates a debt obligation; Interest repayment affect income statement and cash flow; Collateral is usually required by the bank and it can increase the length of time to break-even in a start-up venture (Herrington et al, 2008).

Commercial bank finance model: According to Demirgüç-Kunt et al. (2006), the two primary sources of external finance for new small businesses are equity and debt. External equity in the form of venture capital or the stock exchange or bank credit facility is usually not available for new small businesses. Venture capitalists often enter the firm at the middle or later stages of its lifecycle. The lack of venture capital funds makes many new small businesses dependent on bank loans and overdrafts and suppliers' credit for early-stage financing, which is also known as unstructured lending (FinScope Survey, 2010). 
Factors that are taken into consideration by commercial banks' finance model to assess Small Enterprise assets credit application are:

1. Character: Business and Owner's credit history based on credit score; Trade references - reputation of business with suppliers and customers; Letter of good standing - bank report based on existing relationship with the potential lending institution; Management skills and experience; Years with Bank; Owner's personal credit history; Experience (years) in Business and Type of Legal Entity

2. Capital: Leverage of the business, normally measured by the debt-asset ratio; Client contribution to financing; Average bank account turnover / Turnover from income statement; Average bank account balance; Strength of balance sheet.

3. Capacity: Business profitability and volatility of income; Existing and projected cash flow; Financial ratios including profitability ratios, liquidity ratios, efficiency ratios, debt ratios with interest cover being one of the most important (Total Sales, Loan Size as \% of Sales, Total Debt/Equity, Current Ratio, Inventory Turnover, Interest Coverage, Debt Coverage Ratio).

4. Collateral: Normally in the form of fixed assets or loan; Guarantees; Loan to Value ratio; Type of collateral and Presence of additional guarantees.

5. Cycle: Macroeconomic cycle: rate of economic activity; economic growth; rate of unemployment; GDP; Consumer Price Index; production.

6. Industry: Industry performance; Performance of business relative to its competitors and the overall industry; Consumer demand; The bank's current exposure to the industry sector risk appetite and The bank's impairments relating to the industry sector.

7. Loan: Amount of the loan, interest charged by the bank and loan maturity

Gupta's (2009) approach to risk assessment of small businesses finance applications includes the following:

- Industry: Correlation with industry trends, corporate linkages and length of relationships.

- Business: Length of operations and sustainable levels.

- Management: Experience, collateral and market standing (trade references).

- Financial: Sales, cash flows and availability of informal credit.

- Transactional: Payment history, cash flows, defaults, return of collections etc.

There are no standard criteria for credit lending since banks tend to set their own credit lending policies. Furthermore, the commercial banks use a point system on each listed factor above to count the number of good and the number of bad contracts finalized for, across each possible "category". The purpose of the point system is to assess the Small Enterprise client portfolio for meaningful patterns of increasing or decreasing risk. The point system assigns point weights equal to the concentration of bad loans per category, the higher the risk the higher the rate.

Credit scoring model: Commercial banks credit scoring system to assess Small Enterprise assets finance applications allows consistent, standardized and transparent measures to lending risk. The credit scoring also provides a quantitative estimate of a borrower's risk, allowing for differentiation in the loan approval process, loan conditions and pricing collection activities. The commercial bank indicates that the credit scorecard assesses the client's probability to default 
Mtsweni, L., Serumaga-Zake, P. \& Kruger J. W. (2020) Factors of commercial banks' loan eligibility of Small Businesses in South Africa: A construction industry case. Advances in Social Sciences Research Journal, 7(3) 416-430.

based on the client's history of payments, and gives an indication of the profitability of such a transaction.

The commercial banks credit scoring models benefit the banks when used and managed appropriately and can harm if not managed properly. The potential disadvantages of the credit scoring system not properly developed, implemented, or managed effectively are: Scorecards may rely on inaccurate or unreliable data; Scorecards may not be adequately monitored; Managers must provide effective training to users to ensure usage according to policy and Scorecards can lose effectiveness or be inaccurate for a variety of reasons.

Loan application form: The contents in the credit application form cover issues like the length of service in business, business and owners' personal details and awareness of available financial assistance.

The business information includes: company and owner's profiles, types of legal entity, shareholders, ownership, banking details and years with the bank, credit history and most importantly a clear credit record (no bad listing). The purpose of the company and owner's background is for the bank to determine the applicant's profile in terms of credit history. The banks require detailed information about the entity and its owner, when the entity was established, experience of owners in the business to determine stability of the business. The commercial bank then uses internal credit check systems to validate the information such as Experian, ITC check, CIPRO etc.

\section{RESEARCH METHOD}

The research used multiple case study to examine and understand similarities and differences between approved and declined asset finance applications by small businesses in the construction industry.

Qualitative Approach: In-depth interviews conducted with three senior credit managers from one randomly selected commercial bank and six small enterprise clients in the construction industry (i.e., three approved and three declined loan applicants). Data, from the recording device, was transcribed to Microsoft excel document and thematically analyzed.

Validity and reliability of data were achieved by triangulating the data using documentary analysis, which involved the bank's official relevant documents as well as businesses' complaints and received feedback from the bank (i.e., after the completion of the credit assessment by the commercial bank).

Businesses were randomly selected from the bank's database. Bank officials were purposively selected from the credit and asset financing departments. They had expertise and at least 3 years of service in the department, and so, had the relevant knowledge and could give sufficient input to the research study. Incomplete cases were totally excluded, but the exclusion, is also a finding. In such cases, the researcher noted the profiles thereof e.g. company size, industry and ownership, as well as the BBBEE scorecard thereof. 
The profile of construction small businesses used in the study (i.e., extracted from the first section of the application forms) were in operation for approved applications $(10,14,6$ years $)$ versus declined applications $(10,10,4$ years). Number of directors for approved $(3,2,1)$ versus for declined $(3,1,1)$. Turnover for approved applications (R300k, R500k, R600k) and for declined (R200k, R0, R600k). Their overdraft facilities were for approved (R300k, R500k, R600k) and for declined (R200k, R0, R250k). All six applications cleared by Credit bureau (ITC). The approved applications could provide surety, to secure the funding while the declined applications did not provide surety to cede for the facility. Deposit for the approved applications were minimal, while for the declined applications it had a cash flow impact.

\section{Approved firm assets finance applications}

\section{DATA ANALYSIS AND DISCUSSION}

The applicants had been in family business for at least 6 years. Some members had at least 20 years' experience in the construction industry and engineering qualifications. They all had good credit history with good repayments on their accounts and no arrears. The typical relationshipbased term loans were based on a business relationship built over years of lending, which allowed for a substantial flexibility in loan terms. All the accounts that applicants had realised increased in their turnover from the previous year. One had realised a loss of R300 000 due to high operational expenses on subcontracting experienced and this challenge could have been eliminated if the business owned their assets and used their own skilled labourers to reduce high costs. However, the business is in good standing, credit facility and has been profitable over the years and their balance sheet reflected a high equity ratio that placed comfort to the bank to grant additional credit facility on acquiring the assets that assists the business to increase their turnover and profits. Two applicants operated from rented business premises. The applications indicated that leveraged finance was required because the applicants demonstrated sustainable and predictable cash flows.

The banks required the business audited latest financials and any other financial supporting documents (Balance Sheet, Income Statement, Cash Flow, Changes in Equity, Management Accounts and Assets and liabilities). With all three cases debt and turnover ratios reflect that the business is solvent and the business is profitable and add back the depreciation.

All applicants had solvent businesses with notable profitably. A long-term relationship funding arrangement allows the bank to offer concessionary rates to a borrower facing temporary credit problems, which the bank can later make up for when the firm returns to health (Brewer, 2007).

\section{Needs and purpose of the required finance.}

Musara \& Fatoki (2010) allege that the ability of start-up small businesses to grow depends strongly on their potential to have fixed assets and working capital for operations, the main components of Grunhagen \& Mittelstaedt's (2002) model. The commercial banks evaluate the purpose of the required finance for each application and deliberate on the relevance thereof. The need of the credit facility should be legal, validated and in line with the applicant's core business interest. Deakins \& Freel (2003) indicated that the business start-up process can be divided into a number of stages, idea formulation, opportunity recognition, pre-start planning and preparation, entry and launch, and post-entry development. 
Mtsweni, L., Serumaga-Zake, P. \& Kruger J. W. (2020) Factors of commercial banks' loan eligibility of Small Businesses in South Africa: A construction industry case. Advances in Social Sciences Research Journal, 7(3) 416-430.

Case 1: The company needs 2 TLB's (Truck Loader backhoes) as an addition to the business due to high demand and to reduce maintenance costs and time as the other TLB's are old. The new TLB's are more reliable and more work can be completed on time.

Case 2: The company needs 2 excavators TLB's as an addition to the business due to an additional work that is underway in two different regions and contracts are signed.

Case 3: The company needs 3 vans as an addition to the business to deliver the mining supplies of the secured contract. The purchase of the 3 vans is cheaper than renting as they can be used on other sites as well to save subcontract costs.

All the businesses managed to submit applications with clearly outlined needs and reasons for the assets as well as quotations showing the costs and discounts. The quotations were all from reputable suppliers or manufacturers as stipulated by the commercial bank.

All applicants applied for additional assets (one required TLBs, one excavator and the other required vans). Motivation for applicants was mainly for reducing operational costs.

\section{Risk Mitigation and Repayment ability.}

Commercial banks require company risk and repayment ability mitigated through the company cash flows and to highlight the industry risk and expectations in the market (such as strikes). In addition, the system can determine the chances of a client defaulting on repayment of the loan and classify the risk category, for example, businesses with a default grading of 1-15 is low risk whereas 15 and above is high risk to the bank.

For all three the companies The risk is minimal as the company has a great proven financial history; Affordability is in line based on the strength of the business and the turnover and the company is able to honour its obligation.

Case 1: The main member (father) owns another paving company, only director and this generate the secondary source of income should the business fail.

Case 2: The main member is very experienced. The family is in the same industry/business to support each other.

Case 3: Shows growth in turnover. The main members are very well known in the industry and experienced

An internal behavioural score system is a tool used by banks to check the client's affordability through the bank account conduct in terms of returns, access and how other existing loans are serviced and if the client is not over exposed or committed. Banks have put in place internal exposure policies in place to guide them on maximum loans to be borrowed to businesses, term on the loan, rate to be charged, when to expand, maintain and reduce a credit facility. The results show that none of these applicants had any approved contracts for submission to motivate their application and strengthen the transaction, assuring that there is low risk. The collateral and security for each applicant was also analysed by the commercial bank. 


\section{Collateral/Security}

The security can be signed by all members as per their ownership contribution to the business and in their own capacity or business. The purpose of security is to cover the banks' loan should the client fail to pay the debt. All the applicants' show that they managed to cede security in the form of fixed assets, surety or loan guarantees to the value of the financed amount. One applicant submitted their article as surety for the loan application.

\section{Finance applications for declined loan businesses.}

All declined applications show that they have been in business for just about 10 years, carried a bachelor in commerce qualification with management skills and lacked construction skills unlike the approved applicants. In terms of credit, declined applicants had a poor credit history with only fair repayment rates and one had arrears on existing accounts. Their credit standing negatively affected the commercial bank's business relationship with these businesses which should have been built over years of lending. All the declined applicants had realised some increases in their turnover from the previous year, however, it was not significant growth because of poor industry performance and they were not able to sustain their existing debts. The net profit margins were low and they had already exhausted all the credit facilities like term loans, overdrafts and credit cards. One applicant still had a high outstanding home loan. All declined applicants failed to demonstrate sustainable and predictable cash flows including supporting documents like contracts to support their applications.

In line with the Global Bank report (2015), a number of checks and balances are put in place by the financial industry to manage the risk associated with financing Small business assets. Bank regulations are a form of government regulation which subject banks to certain requirements, restrictions and guidelines. This regulatory structure creates transparency between banking institutions, the individuals and corporations with whom they conduct business, among other things. Given the interconnectedness of the banking industry and the reliance that the national (and global) economy holds on banks, it is important for regulatory agencies to maintain control over the standardized practices of these institutions. (www.globalbankreport.co.za). The client's contribution to financing to maximise risk is known as deposit to the financed amount. Furthermore, the client doesn't have to bank with the same bank when borrowing money. Other banks simply require six-month statements.

The declined applicants reflected a very low increase on turnover and net profit margins.

Case 1: The turnover and profit margin ratios on the company reflected a low increase margin of $6 \%$ in 2012 and only $8 \%$ in 2013, net profit after tax increased from R781k to R1.4m. However, the business liabilities and debt gearing ratio were higher that the industry norm of $5 \%$, it improved from $7.63 \%$ in 2012 to $6.13 \%$ in 2013 . This simply means that the business was indebted and reducing their debts are reducing slower and over a long term; The business has unencumbered assets which are already used as collateral on the existing loans; The business is profitable, adding back the depreciation and the affordability of the required finance is not in doubt.

Case 2: The turnover of the client showed a small increase of 5\% in 2013 and had a potential growth of $14 \%$ should the bank finance the asset and according to the cash projection made. The 
Mtsweni, L., Serumaga-Zake, P. \& Kruger J. W. (2020) Factors of commercial banks' loan eligibility of Small Businesses in South Africa: A construction industry case. Advances in Social Sciences Research Journal, 7(3) 416-430.

business offerings are still not well known in the market and only cater for clients that are familiar with the concrete-marbles flooring; The business is solvent. However, it reflects a debt balance of R2.3m in the business and client name and slow growth to sustain the current debt and the business is profitable, adding back the depreciation, affordability was out of line taking the probability of interest rates, increase and inflation versus the current business growth rate.

Case 3: The business turnover and profit margin is reflecting a low margin growth of $5 \%$ in 2013; The company has no existing loans. However, during the visit the business seemed slow and surrounded by similar businesses around the area and the business is solvent and profitable; adding back the depreciation to substantiate affordability puts strain on the daily management of the business. The bank account is already reflecting a fair status on its conduct. Furthermore, their existing debt ratios were highly geared which poses so much risk to the bank and there is a high probability of the applicants defaulting payments, leading into the article to be repossessed and the client losing other assets such as properties if ceded as collateral. Even the addition of depreciation to the net profit amounts, to increase affordability, did not significantly improve their chances of meeting the credit criteria of the bank. The other member had challenges in providing the banks with information required and presenting proof to convince the bank to accommodate their credit requests.

The assessment of financial performance by banks is in line with the World Bank report (2015), the Small Enterprise had cash flow difficulties which were significantly reduced in firms that kept a cash book, kept a record of debtors, practised active debtor management and controlled inventory. Implementing any of these practices was associated with a minimum of $33 \%$ reduction in the probability of an exhausted overdraft and doing all four appeared to reduce this probability by as much as $61 \%$. Implementing these practices also significantly increased the probability that a firm would succeed in an application for term loan or assets finance. The GEM (2003) report concluded that a policy priority in SA was implementing programmes, including mentorship and training programmes that addressed the apparent financial management weaknesses in many small businesses (Orford et al., 2003).

A 2007 study by the World Bank reveals that barriers to accessing loans in South Africa's banking institutions were very low. South African financial institutions take an average of 4.13 days to process a Small Enterprise loan as compared to an international average of 11.03 days. It is a fact that a Small Enterprise credit application takes around two times more days than other corporate business loans. This is probably owing to the lack of quality information being provided on the part of applicants.

The commercial bank also complies with the relevant regulations in SA. Some of these include financial performance. The purpose of the financial performance of the business is to determine any changes such as selling of assets, financial strategy, financial challenges faced by the business and the financial strength of the business. The banks have ratios in place to assist in reviewing the leverage of the business, normally measured by the debt-asset ratio, business profitability and volatility of income, existing and projected cash flow, financial ratios including profitability ratios, liquidity ratios, efficiency ratios and debt ratios with interest cover being one of the most important (Total Sales, Loan Size as \% of Sales, Total Debt/Equity, Current Ratio, Inventory Turnover, Interest Coverage, Debt Coverage Ratio). 
It is important for the bank to analyse the following, through the financial statements:

Capital Structure - The net worth of the business through the assets versus liabilities, their gearing ratios which determine who take the most risk the bank or the client through the deposit and if there are hidden reserves or deficit.

- Operating performance - An analysis of profit ratios, trend of revenue increase or decline and the key drivers.

- Liquidity - The operating cash flow of the business, current and quick ratios to establish how quick the client can turn their stock into cash, debtor, credit and stock ratios and their spread in terms of how quick the client collects from their debtors and cash flow statement

- Debt service - How well does the client service their existing debts, interest/debt cover ratios, amount and type?

- Management accounts - The bank normally assess the performance of the business against the cash flow projections over 6 to 12 months period.

The needs for declined applicants were similar with those of the approved; mainly for business expansion and to increase capacity.

Case 1: The company requires 2 trucks as an addition on the business to accommodate the requirement of the new constructions contract to build an office park. A new truck is more reliable and more work will be completed on time.

Case 2: The company requires the concrete machine as an additional article to generate more income and expand the business. The need for the new machine is to modernise and speed up operations. This new machine allows the client to take on larger jobs and perform the same task in half the time. At present the client has been awarded a major contract for June (2014) ending in November (2014) valued at R7.8m but the contract is not signed.

Case 3: The company requires 2 tipper trucks as an addition on the business to deliver the sand and concretes. The need of the trucks is to expand the business to grow their clientele and be able to deliver clients orders on time and quicker.

The major hurdle for declined applicants was along the performance of the business which would reduce their deposit amounts. These findings are in relation to the Banking Association of South Africa (2013) which indicates that the South African population consists predominantly of lower income earners who had limited or no access to regular credit channels. Coming from poorer backgrounds, the lack of finance for these declined applications worsen their ability to access funding which would expand their business. Declined applicants showed that there was a risk of financial strain on their cash flow if applications are approved based on their credit history, financial performance and low deposit amounts.

For all three cases the risk is minimal as the company has a great proven financial history; Affordability is in line based on the strength of the business and the turnover and company is able to honour its obligation. 
Mtsweni, L., Serumaga-Zake, P. \& Kruger J. W. (2020) Factors of commercial banks' loan eligibility of Small Businesses in South Africa: A construction industry case. Advances in Social Sciences Research Journal, 7(3) 416-430.

Case 1: The members own the other distribution company, only director and this generate the secondary source of income should the business fail.

Case 2: The client to sign the unlimited surety and based on the new contracts received, the business is able to afford this new instalment payment, reflected on the cash flow projection.

Case 3: The previous repayment amount is similar to the previous amounts on settled accounts and turnover reflects an increase year on year. The main member is very well known in the industry and experienced.

Members already signed surety on other existing loans and the new surety puts the commercial bank at risk should the client default payment because the applicants are overexposed by signing all business assets and the once in their capacity away.

In all three cases the assets to be financed would be ceded to the bank as collateral.

Case 1: All members are signing unlimited surety as per their ownership contribution to the business for the financed amount. However, they already had existing loans in the business name and in their own capacity and their fixed assets and investments were already ceded. This poses a high risk to the bank should they default payment or failure in their business.

Case 2: The member was signing unlimited surety to the business for the financed amount. The client is willing to cede R1million of his own property to cover a portion of the finance as the client property is only bonded for R1.25million and the property is worth close to R3 million. All other fixed assets were already ceded to the banks for other finance.

Case 3: The member was signing unlimited surety of his R100k investment to the business for the financed amount; The client's proposed investment cover was very low against the finance amount of R1m and he had no property in his name as the property was sold and profit was used as capital to start the business.

Banks usually consider the financed assets as the collateral. However, an additional security is required on specialised assets as the bank can face a risk of failing to sell the assets or at no value. The collateral requirements on finance within the banks are in line with a study conducted by Mail \& Guardian (2013), that small businesses in South Africa are meant to create jobs and grow the economy but a highly concentrated economy, a poorly skilled workforce, stringent red tape, a high failure rate and a lack of an entrepreneurship culture are all affecting the sector's performance.

Furthermore, entrepreneurs across various sectors are experiencing challenges in accessing financial assistance to start or grow their business through financial institutions (Maas \& Herrington, 2008). This is due to rigid lending criteria and not meeting set requirements, including collateral securities (FinScope Small Business Survey, 2010). Hussian et al. (2006), state that when the cost of survival or growth in firms exceed the availability of financial resources owned or controlled by owners, they become dependent on the availability of external sources of finance. 
Compliance of approved and declined applications: Compliance is an important aspect of any bank as most of these legislations are proposed and implemented by the government to protect both clients and the banks against reckless lending, money laundering, knowing your customers (FICA), FAIS and so forth. The banks have put monitoring systems in place to ensure that they comply with the requirements and don't face fines or lose their licence. All applicants were compliant with all the required stipulations for FAIS, FICA, CASA, BEE and NCA.

The credit team from the commercial bank summarises their findings with recommendations on the application sheet. The recommendation on the credit application summarise the entire motivation. Based on the results a decision is finally made based on the recommendations and in line with the banks credit policies. The decision has two outcomes either a decline or an approval. The decisions:

Case 1: Good bank client since 2008; Well conducted account with no returns and access; Good increase on turnover and Existing assets finance client, good track account paid well and $20 \%$ deposit, 48 months, VAT back paid month 2 - 7 .

Case 2: Good bank client since 2005; Well conducted account with no returns and access; Good increase on turnover and potential growth of $14 \%$ year on year expected; Existing assets finance client, good track account paid well and 20\% deposit, 48 months, VAT back paid month $2-7$.

Case 3: Good bank client since 2001; Well conducted account with no returns and access; Good increase on turnover; Existing assets finance client, good track account paid well and $20 \%$ deposit, 60 months, no VAT back required.

Approved and declined loan applicants: Based on case study results, it was clear that all approved applicants had good track records, with accounts that were not overdrawn, previous good payment profiles, increasing turnover and profits, financially sound from the previous years, high deposits were paid to secure the lending and thus showed commitment to the banks. These applicants were able to carry the Vat back portion upfront as banks only finance the capital amounts, they demonstrated less risk to the bank in terms of affordability and all company members had existing assets to serve as surety. Furthermore, the approved applicants were very experienced in this industry and could present additional documentations such as signed contracts, cash flow projection over a year to support the lending. Most companies were family businesses and some had strong support from family members in the similar business.

On the declined cases, the businesses could not meet the minimum deposits criteria. Some of the applicants were overexposed to qualify for additional finance and had already ceded their assets to the existing outstanding loans. There was only one Small Enterprise applicant director's structure made up of family members while others were wholly owned by one member with limited experience in the industry and minimal skills and qualifications. The declined applicants' financial status in terms of their turnover and profit margin growth was low and unstable posing a risk to the banks decision of granting additional finance. In addition, the declined applicants failed to present supporting information such as signed contracts, cash flow projections unlike the approved applicants to strengthen the banks decision in approving their finance requests. 
Mtsweni, L., Serumaga-Zake, P. \& Kruger J. W. (2020) Factors of commercial banks' loan eligibility of Small Businesses in South Africa: A construction industry case. Advances in Social Sciences Research Journal, 7(3) 416-430.

The analysis outcome can be related to Malik Fal, the managing director of the Omidyar Network Africa, which promotes and funds high-impact entrepreneurs. Omidyar's Accelerating Entrepreneurship in Africa survey released in April (2014) reveals that South Africa's small businesses are held back by four main challenges:

1. Business regulations

2. Access to a skilled workforce or business skills

3. Access to finance and lack of collateral

4. Poor quality of financial statements and business plans.

\section{CONCLUSION, IMPLICATION, SUGGESTION, AND LIMITATIONS}

Commercial banks rely on the available information, figures and statistics under their custody. There is a concern of poor quality of credit applications and clients, in general, do not supply sufficient required documentation or additional information to mitigate the risk and support the applications. High pricing on interest rates, short term of finance, high upfront deposits and service fees charged by the commercial banks on repeat buyers and assets to be used to grow the business are big issues.

It was found that client's relationship and background, character, collateral, capital, capacity and affordability are major factors of loan eligibility of small businesses in South Africa. Of particular importance is that, typical relationship-based term loans are based on a business relationship built over years of lending, allowing for substantial flexibility in loan terms.

The commercial bank may consider improving their current credit system and allow small businesses to have an option of applying for credit online. This would reduce the amount of poor quality applications submitted. The banks should also have controls in place not to proceed with the application until all supporting documents are supplied. Commercial banks may consider reviewing their pricing and finance policy, considering pricing according to the period of their relationship with the client. They should also review the finance policy on collateral requirements as the financed assets are automatically ceded to the bank, which should be enough to minimise the banks"e risk.

The credit policy should allow flexibility per industry in terms of the maximum finance terms, minimum deposits and interest rates charged. For example, where new assets are financed the commercial banks should allow the finance term to be more than 4 years, to stretch the repayment amounts and ease the high instalment burden.

Banks funding requirements make it difficult for B-BBEE companies, especially small ones to attain the funding. The access to funding is highly dependent on whether the company exists on the bank's system, thus making it difficult for new small companies. There is a need for improvement in this regard. Banks should reduce funding requirements needed to attain the loans for a lot of the B-BBEE companies as they do not fit within the bank's risk profile or the criteria used for selection. Banks should partner with the government (DTI) and align the funding requirements to some of the government grants or schemes in place for SME's. This might benefit the Banks that partner with SME's and strengthening their BBBEE scoring rate. 
Programmes for small businesses may have to be formulated to do basic business administration, and these should be carried out in conjunction with other stakeholders such as Small Enterprise Development Agency (SEDA), Independent Development Trust (IDT) or other government entities.

\section{References}

Albanese, A 2009, Fairer compensation for air travellers, media release, 29 January, Minister for Infrastructure, Transport, Regional Development and Local Government, viewed 30 January 2009, <http://www.minister.infrastructure.gov.au/aa/releases/2009/January/AA007_2009.htm>.

Australian Government Publishing Service 1987, Commonwealth printing and publishing manual, $2^{\text {nd }}$ edn, A.G.P.S., Canberra.

Be, know, do: leadership the Army way 2004, Jossey-Bass, San Francisco.

Berkman, RI 1994, Find It fast: how to uncover expert information on any subject, Harper Perennial, New York.

Bernstein, D 1995, 'Transportation planning', in WF Chen (ed.), The civil engineering handbook, CRC Press, Boca Raton, pp. 231-61.

Bhattacharjee, M 1998, Notes of infinite permutation groups, Lecture notes in mathematics no. 1698, Springer, New York.

Bliss, SE n.d., The effect of emotional intelligence on a modern organizational leader's ability to make effective decisions, viewed 10 February 2008, <http://eqi.org/mgtpaper.htm>.

Bourassa, S 1999, 'Effects of child care on young children', Proceedings of the third annual meeting of the International Society for Child Psychology, International Society for Child Psychology, Atlanta, Georgia, pp. 44-6.

Bowden, FJ \& Fairley, CK 1996, 'Endemic STDs in the Northern Territory: estimations of effective rates of partner change', paper presented to the scientific meeting of the Royal Australian College of Physicians, Darwin, 24-25 June.

Cengel, YA \& Boles, MA 1994, Thermodynamics: an engineering approach, $2^{\text {nd }}$ edn, McGraw Hill, London.

Cookson, AH 1985, Particle trap for compressed gas insulated transmission systems, US Patent 4554399.

Daniel, TT 2009, 'Learning from simpler times', Risk Management, vol. 56, no. 1, pp. 40-44, viewed 30 January 2009, <http://proquest.umi.com/>.

Dawkins, R 1996a, Climbing Mount Improbable, Viking, London.

Dawkins, $R$ 1996b, River out of Eden, Phoenix, London.

Department of Mines and Energy, Queensland 1996, Dotswood, Australia 1:100 000 geological series, sheet 8158, Department of Mines and Energy, Queensland, Brisbane.

Donahue-Wallace, $K \&$ Chanda, $J$ 2005, 'A case study in integrating the best practices of face-to-face art history and online teaching', Interactive Multimedia Electronic Journal of Computer-Enhanced Learning, vol. 7, no. 1, viewed 30 January 2009, <http://imej.wfu.edu/articles/2005/1/01/index.asp>.

Exelby, HRA 1997, 'Aspects of gold and mineral liberation', PhD thesis, University of Queensland, Brisbane.

Huffman, LM 1996, 'Processing whey protein for use as a food ingredient', Food Technology, vol. 50, no. 2, pp. 49-52.

International Organization for Standardization 1982, Steels - classification - part 1: classification of steels into unalloyed and alloy steels based on chemical composition, ISO 4948-1:1982, International Organization for Standardization, Geneva.

Jull, G, Sterling, M, Fallah, D, Treleaven, J \& O'Leary, S 2008, Whiplash headache and neck pain: research-based directions for physical therapies, Churchill Livingstone, Edinburgh.

Mortimer, M. \& Cox, M 1999, Contaminants in mud crabs and sediments from the Maroochy River, Environment technical report no. 25, Queensland Department of the Environment, Brisbane.

Pike, ER \& Sarkar, S (eds) 1986, Frontiers in quantum optics, Adam Hilger, Bristol.

Porteous, C 2007, 'Rudd blamed for drought', Courier Mail, 15 August, p. 17, viewed 27 February 2009, $<$ http://global.factiva.com/>.

Pring, R 2004, Philosophy of educational research, $2^{\text {nd }}$ edn, Continuum, London. 
Rathbun, AH, West, J \& Hausken, EG 2003, Young children's access to computers in the home and at school in 1999 and 2000, NCES-2003-036, National Center for Education Statistics, Washington, DC, viewed 4 November 2003, $<$ http://nces.ed.gov/pubs2003/2003036.pdf>.

Simpson, L 1997, 'Tasmania's railway goes private', Australian Financial Review, 13 October, p. 10.

Sjostrand, $S$ (ed.) 1993, Institutional change: theory and empirical findings, M.E. Sharpe, Armonk, N.Y.

University of Queensland Library 2009, Mechanical engineering subject guide, University of Queensland Library, viewed 6 February 2009, <http://www.library.uq.edu.au/findits/findit.php?title= Mechanical+Engineering .

Willmott, WF 2004, Rocks and landscapes of the national parks of southern Queensland, Geological Society of Australia, Queensland Division, Brisbane.

Willmott, WF 2006, Rocks and landscapes of the national parks of central Queensland, Geological Society of Australia, Queensland Division, Brisbane. 